\title{
ON THE STRATIGRAPHY AND PETROGRAPHY OF THE TUOMIVAARA IRON FORMATION IN SOTKAMO, NORTHERN FINLAND
}

\author{
KAARLO MÄKELÄ
}

\begin{abstract}
MÄKELÄ, KAARLO 1976: On the stratigraphy and petrography of the Tuomivaara iron formation in Sotkamo, northern Finland. Bull. Geol. Soc. Finland 48, 71-86.
\end{abstract}

The Tuomivaara iron formation is an example of a chemically sedimented, strata bound occurrence of Pre-Cambrian age. It is characterized by a relatively large volume of silicate facies, while the economically important oxide facies is in a subordinate position. The general stratigraphy of the Tuomivaara area is given, and the petrography of the iron formation horizon is described in more detail. Some economic aspects are presented. The origin of iron formations is discussed.

Kaarlo Mäkelä, Malminetsintä, Rautaruukki Oy., SF-90100 Oulu 10, Finland.*

* Present address: Outokumpu Co., P.O. Box 27, SF-02101 Espoo 10, Finland

\section{Introduction}

The Tuomivaara iron formation is located in the the so called Tuomivaara belt of the Karelian schist zone in the parish of Sotkamo, central northern Finland (Fig. 1). The belt is easily accessible along the road 899 appr. $30 \mathrm{~km}$ East of Kajaani. Good exposures of iron formation are found along, or in the vicinity of, the road 901. The Nurmes-Kontiomäki railroad runs almost on the iron formation.

Topographically the Tuomivaara and Naapurinvaara hills, both being built of iron formation and related rocks, make pronounced landmarks in the otherwise rather modestly reliefed surroundings of the Tuo- mivaara belt. Appr. $6 \mathrm{~km}$ South of Naapurinvaara stands the Vuokatti hill, which, being built of Karelian quartzites, forms the highest point in the district.

The Tuomivaara iron formation has been long known for its magnetite contents (Wilkman 1921, 1924; Väyrynen 1933, 1954; the Suomen Malmi and Rautaruukki companies' private reports). The material for this study was obtained from the previous geological mappings and diamond drillings by Rautaruukki Oy. on the Tuomivaara deposit, and from the field work conducted by the present author on the continuations of the Tuomivaara iron formation to the South (the Naapurinvaara area) and to the North (the Paakki area) in 1974. 


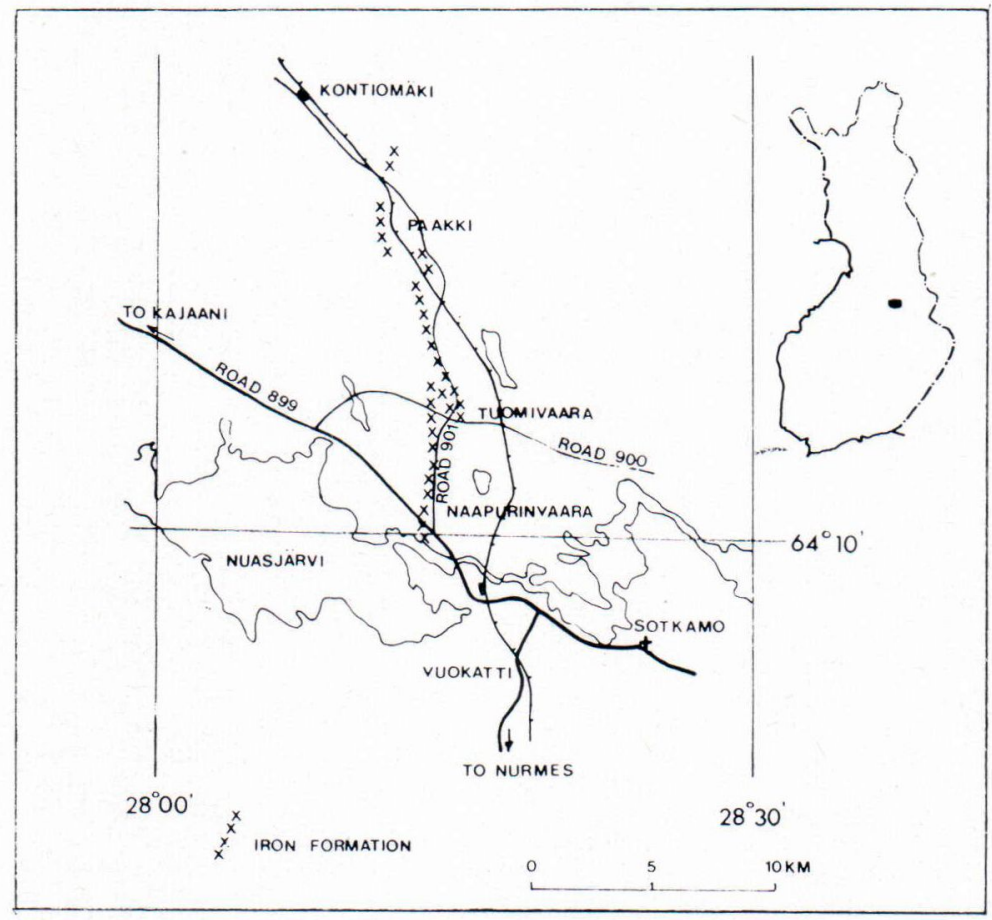

Fig. 1. Location of the Tuomivaara area.

The purpose of this paper is to describe the lithology and petrology of the Tuomivaara silicate facies dominated iron formation and related rocks, to give the stratigraphy of the Tuomivaara belt in general terms, and to discuss some points in the problematics of the strata bound iron ores.

The microscope examinations for the present study were carried out by the writer at the Exploration Department of Rautaruukki Oy., Oulu. The analyses presented in this paper are routine XRF-rock assays of the Research Laboratory of the Raahe Steel Works of Rautaruukki Oy.

\section{Stratigraphy and petrography of the Tuomivaara area}

The Tuomivaara belt belongs to what is called the Karelian schist zone of the Sveco- karelian orogeny (Simonen 1960, 1971). The sedimentation on this zone has been estimated to have taken place appr. 2.2-2.3 billion years ago (Geological Survey of Finland Annual Report.1972). It borders in the East to the Pre-Svecokarelian granite gneiss complex. The lowermost stratigraphic units of the Karelian formations are the basal formation and quartzites overlain by a local dolomite and a phyllite formation. These formations are the Jatulian continental and epicontinental evolutionary series (Väyrynen 1933, 1954). The phyllite forms a transitional unit to the marine Jatulian which is built of aluminous and ferruginous phyllite and iron formations. These Jatulian formations are overlain by Kalevian phyllites, quartzites, black schists and volcanics. This suite has a flyschoidal character.

Fig. 2 is a simplified geological map, and 


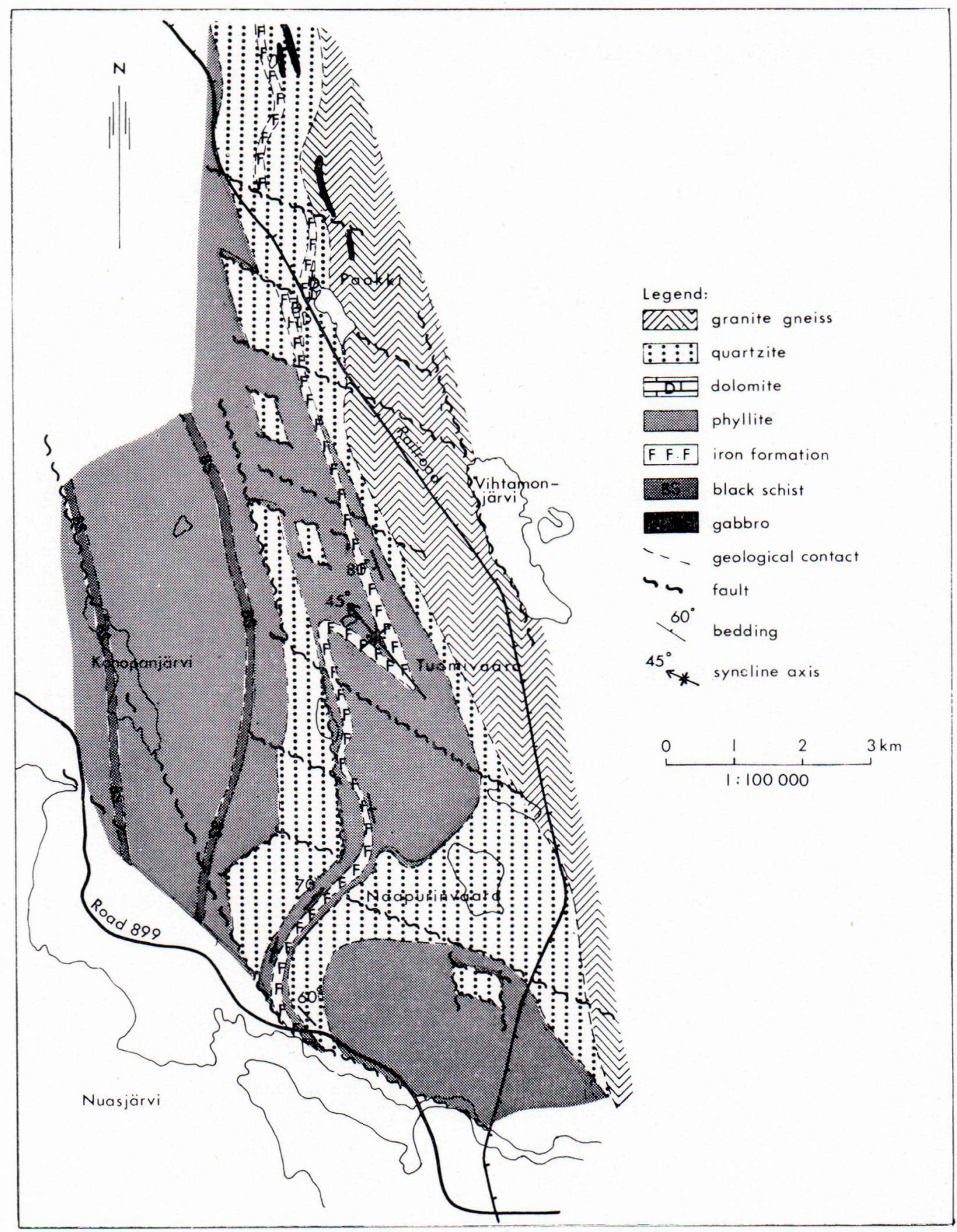

Fig. 2 Simplified geological map of the Tuomivaara area. 


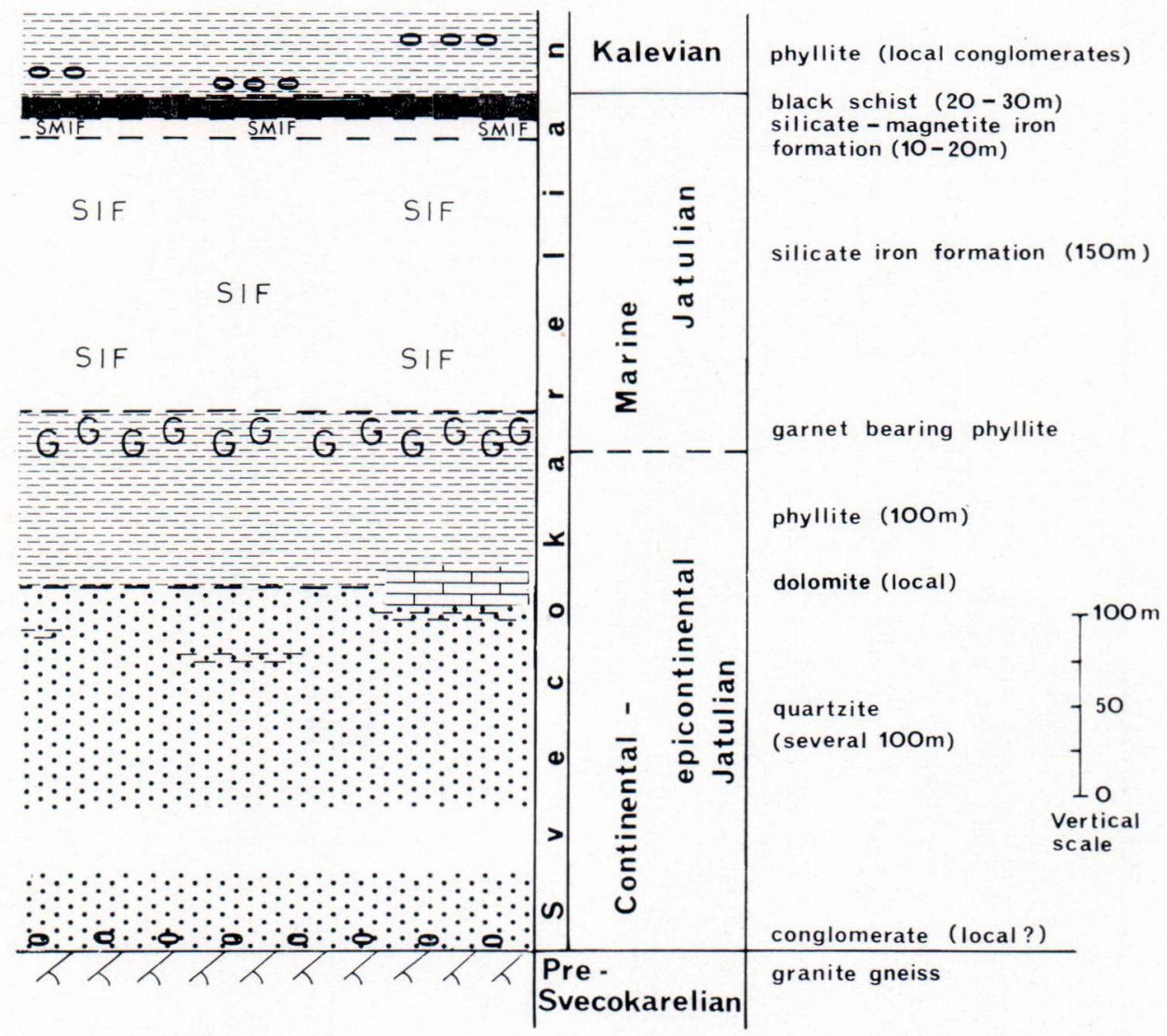

Fig. 3. Stratigraphy of the Tuomivaara area.

Fig. 3 displays the stratigraphy of the Tuomivaara area.

The basement complex. The Pre-Svecokarelian granite gneiss complex is well exposed East of the schist zone. These gneisses are highly migmatized and often homogenized into granite. Several basic, and even ultrabasic, intrusive bodies cut the granite gneiss.

Basal formations. The outcrops of basal formations between the basement complex and the Svecokarelian formations are sparse in the Tuomivaara area. The discordance level is not exposed in the area, and only locally in its vicinity are basal conglomerates found containing rounded quartz and granite pebbles with diameters of $2-3 \mathrm{~cm}$.

Quartzite. The overlying quartzites are clastic and, especially in the lower parts, usually rather coarse grained. Conglomeratic varieties are also met with, the pebble material being mostly quartz. Glassy, massive, and a more clearly bedded orthoquartzite are comon types. The original carbonate content is visible in some places as dissolved pits in certain beds. Towards the top the quartzite becomes more fine grained, and intercalations of phyllite, and even clayey schist, are encountered.

The total thickness of the quartzite is not 
known, but it is estimated to be several hundreds of metres.

Dolomite. A dolomite bed some tens of metres (maximum) thick exists between the quartzite and the overlying phyllite at Paakki, North of Tuomivaara (Figs. 1 and 2). Elsewhere in the Tuomivaara area only a $10 \mathrm{~cm}$ thick pure dolomite band has been found in a drill hole at Tuomivaara.

Phyllite (Jatulian). The quartzite grades upwards into pelitic schists, the phyllite formation. The thickness of this unit is of the order of $100-200$ metres. The phyllite is often dark and graphite bearing resembling »black schist». Aluminous, porphyroblastic (garnet, staurolite) varieties are also met with.

Garnet bearing phyllite. A garnetiferous variety is found as the uppermost unit of the phyllite horizon (Fig. 4). The rock is enriched in iron as compared with the above mentioned phyllite (cf. Table 1). The case is one of mixed clastic and chemical sedimentation the clastic sedimentation being ceasing and the chemical sedimentation taking over; the iron formation is at its initial stage. This garnet bearing phyllite is easily recognized on the outcrops, and it thus makes a good marker horizon. It occurs systematically between the underlying phyllite and the overlying iron formation. The thickness of the garnet bearing phyllite horizon is a few tens of metres (estimated, $30 \mathrm{~m})$.

Under the microscope this rock (specimen 7040102) appears to be composed of garnet, biotite and quartz with the following accessory minerals: tourmaline, apatite, zircon, and a few opaque grains. The diameters of the garnet grains approximate $2-3 \mathrm{~mm}$. Tourmaline is found as euhedral grains (lengths up to $0.2 \mathrm{~mm}$ ) throughout the thin section. The texture of the rock is blastoclastic.

Iron formation. The iron formation makes an appr. 200 metres thick horizon, with

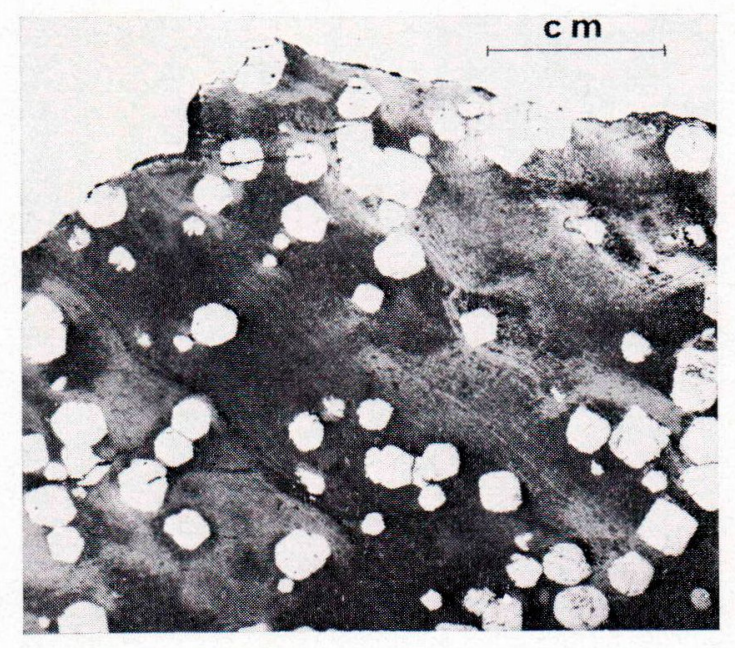

Fig. 4. Specimen 704-0102. Garnet bearing phyllite. Garnet crystals (white) in a fine grained quartzbiotite matrix.

local variations, including the appr. $10 \mathrm{~m}$ thick magnetite rich horizon and the $30 \mathrm{~m}$ thick black schist horizon at the top of the unit. The apparent width may be locally exaggerated due to folding (cf. chapter

\section{Structure).}

The transition from the underlying garnet bearing phyllite to the iron formation is quite clear. The appearance of coarsely grained amphibole and iron sulphides, the coarsening of the grain size of the garnet, and the lack of visible clastic material are the most distinguished features to mark the contact.

On the outcrops and in the drill core the following main lithological types of iron formation are macroscopically identified:

- garnet-grunerite rock ( \pm quartz, pyrrhotite and minor magnetite)

- garnet-grunerite-magnetite rock

- grunerite rock

- quartz-biotite-magnetite rock

- quartz-magnetite ( \pm graphite, grunerite and garnet) assemblage is found close to the top of the iron formation

- quartz-pyrrhotite ( \pm pyrite)-graphite 


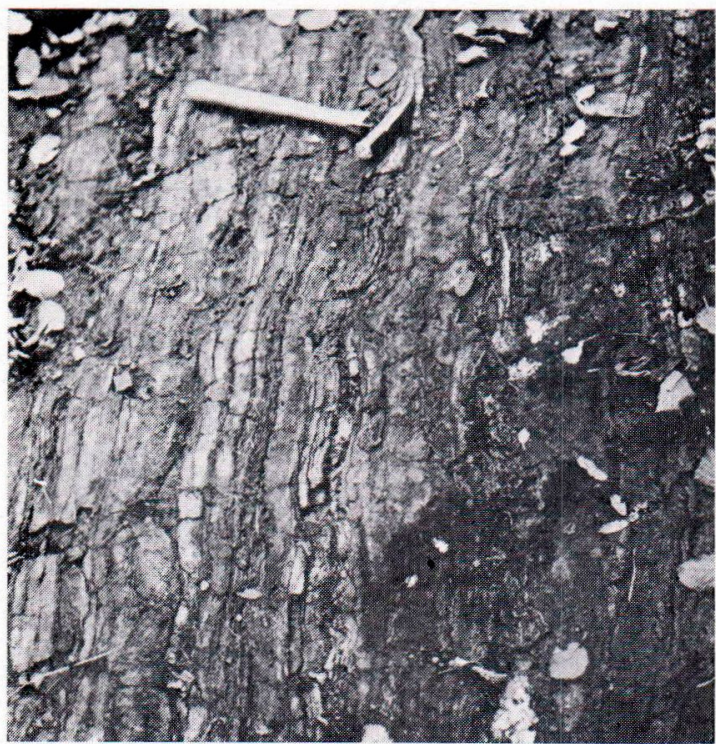

Fig. 5. Outcrop 704-0105 from Naapurinvaara. Typical banded structure in silicate iron formation.

schist (the »black schist», or the "sulphide schist») tops the iron formation horizon.

Graphite is a mineral typical of all of these assemblages forming very fine grained ash-like disseminations in the silicates, and also forming distinct fine grained graphitemagnetite-quartz (chert) layers. Pyrrhotite ( \pm pyrite) is also a typical mineral forming rather pure bands and/or disseminations within the iron silicate bands. Part of the pyrrhotite is mobilized and is now found as fracture fillings (Fig. 18).

The microscopically detected thicknesses of individual bands (microbands) in the iron formation are quite constant: appr. $1-2 \mathrm{~mm}$. In addition, thinner bands $(0.5-1 \mathrm{~mm})$ are also found in the magnetite bearing horizons. Clastic horizons (phyllite) a few centimetres thick are occasionally found in the otherwise pure chemical sediments practically lacking clastic material. Appr. $5 \mathrm{~mm}$ thick chert bands are found throughout the iron formation. Fig. 5 displays an outcrop with the typical banded structure of the Tuomivaara iron formation (mesobands).

In the following, the petrography of the iron formation is given in the light of typical specimens mainly from Naapurinvaara. To compare chemical compositions, please refer to Table 1 .

Table 1 . Analyses of typical Tuomivaara belt rocks. The specimens are described in text.

\begin{tabular}{|c|c|c|c|c|c|c|c|c|c|c|c|c|c|c|c|c|c|}
\hline \multicolumn{2}{|c|}{ Lithological type } & 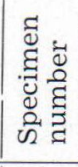 & 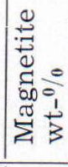 & 出 & 売 & $\overbrace{\substack{n \\
10}}^{10}$ & $\stackrel{0}{\hat{H}}$ & 孞 & $\overbrace{\substack{\infty \\
>}}^{10}$ & $\stackrel{0}{\text { On }}$ & 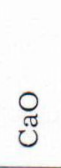 & $\begin{array}{l}0 \\
80 \\
\sum_{i}^{\prime}\end{array}$ & $\stackrel{\leftrightarrow}{4}$ & 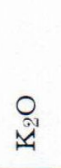 & 仓ั่ & $U$ & $\Omega$ \\
\hline \multicolumn{2}{|c|}{ Phyllite (Kalevian) } & $\begin{array}{l}704- \\
0123\end{array}$ & 0,7 & 5,9 & 7,6 & 0,2 & 0,5 & 0,1 & 0,04 & 69,2 & 2,4 & 2,9 & 11,5 & 3,5 & 0,01 & 1,3 & 0,2 \\
\hline \multirow[t]{2}{*}{ Iron } & $\begin{array}{l}\text { Pyrrhotite- } \\
\text { graphite schist } \\
\text { Magnetite-iron }\end{array}$ & 0126 & 2,5 & 16,6 & 21,3 & 0,2 & 0,3 & 0,0 & 0,09 & 48,0 & 1,3 & 3,4 & 11,8 & 4,6 & 0,00 & 2,4 & 8,9 \\
\hline & silicate rock & 0107 & 11,0 & 31,1 & 40,3 & 0,7 & 0,3 & 0,3 & 0,02 & 41,7 & 2,2 & 4,6 & 5,1 & 0,4 & 0,00 & 0,8 & 0,1 \\
\hline \multirow[t]{2}{*}{ Formation } & & 0113 & 6,3 & 29,8 & 38,3 & 1,8 & 0,2 & 4,2 & 0,02 & 37,1 & 2,7 & 6,3 & 3,0 & 0,1 & 0,00 & 0,9 & 0,1 \\
\hline & $\begin{array}{l}\text { Garnet-grunerite } \\
\text { rock }\end{array}$ & 0101 & 1,6 & 21,3 & 27,4 & 1,1 & 0,3 & 0,3 & 0,02 & 51,2 & 2,2 & 4,8 & 6,2 & 0,6 & 0,00 & 0,8 & 0,3 \\
\hline \multirow{2}{*}{\multicolumn{2}{|c|}{$\begin{array}{l}\text { Garnet bearing phyllite } \\
\text { Phyllite (Jatulian) }\end{array}$}} & $\begin{array}{l}0102 \\
0122\end{array}$ & $\begin{array}{l}1,0 \\
3,3\end{array}$ & $\begin{array}{r}15,4 \\
5,7\end{array}$ & $\begin{array}{r}19,8 \\
7,3\end{array}$ & $\begin{array}{l}0,2 \\
0,2\end{array}$ & $\begin{array}{l}0,7 \\
0,9\end{array}$ & $\begin{array}{l}0,1 \\
0,1\end{array}$ & $\begin{array}{l}0,02 \\
0,04\end{array}$ & 53,7 & 1,1 & 4,1 & 11,2 & 4,7 & 0,01 & 0,3 & 0,3 \\
\hline & & & & & & & & & 0,04 & 62,3 & 0,3 & 1,6 & 18,7 & 6,2 & 0,01 & 2,1 & 0,2 \\
\hline
\end{tabular}




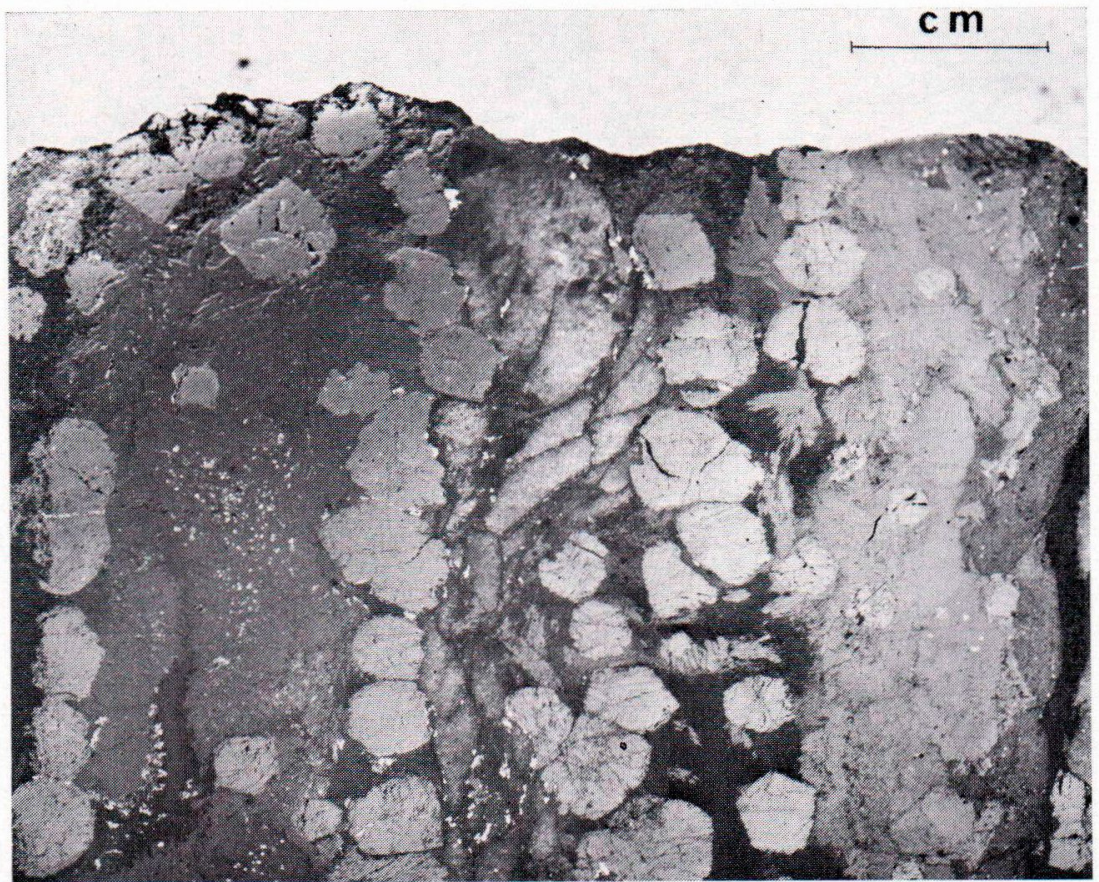

Fig. 6. Specimen 704-0101. Garnet-grunerite-biotite-quartz rock. Garnet crystals (white) in graphite-pigmented biotite-grunerite-quartz bands (grey), and chert bands (white).

\section{Specimen 704-0101 (Fig. 6)}

The constituent minerals of this specimen are garnet, grunerite, biotite and quartz, and the accessory minerals are apatite, carbonate, graphite, magnetite, pyrrhotite and marcasite.

Garnet is found as porphyroblasts up to $7 \mathrm{~mm}$ in diameter. Most of the grains display weak anisotrophism visible in lamellar textures.

Grunerite occurs as porphyroblasts in clastic material and massive biotite. The following optical properties are valid, with only minor exceptions, for all grunerites of the Tuomivaara iron formation.

$$
\begin{aligned}
& \mathrm{c} \wedge \gamma=15^{\circ} \quad 2 \mathrm{Vz} \text { close to } 90^{\circ} . \\
& \gamma=\text { pale yellowish brown } \\
& \beta=\text { very pale yellowish (almost colorless) } \\
& \alpha=\text { almost colorless }(\gamma>>\beta>\alpha)
\end{aligned}
$$

Polysynthetic twinning is common.

Biotite is massive, dark brown to black in color with some green grains.
Quartz is found partly as massive bands (chert?), partly as granoblastic (clastic?) grains.

Graphite occurs as disseminations and as inclusions in silicates except garnet, which does not take graphite inclusions, but pushes the graphite outside and packs it as a tight rim around it (as also in specimen 704-0125, Figs. 13 and 14).

A few raggedy magnetite grains are found in the iron silicate layers. Pyrrhotite and its alteration product, marcasite, are mainly associated with the chert bands.

The texture of the rock is banded, partly granoblastic (chemical sedimentation), possibly partly blastoclastic (quartz grains).

The almandine and grunerite from specimen 704-0101 were analyzed and appeared to contain $27.0 \%$ and $29.8 \%$ total iron, respectively.

\section{Specimen 704-0113 (Fig. 7)}

This rock is composed of grunerite, garnet and biotite with accessory chlorite, hornblende, apatite, 


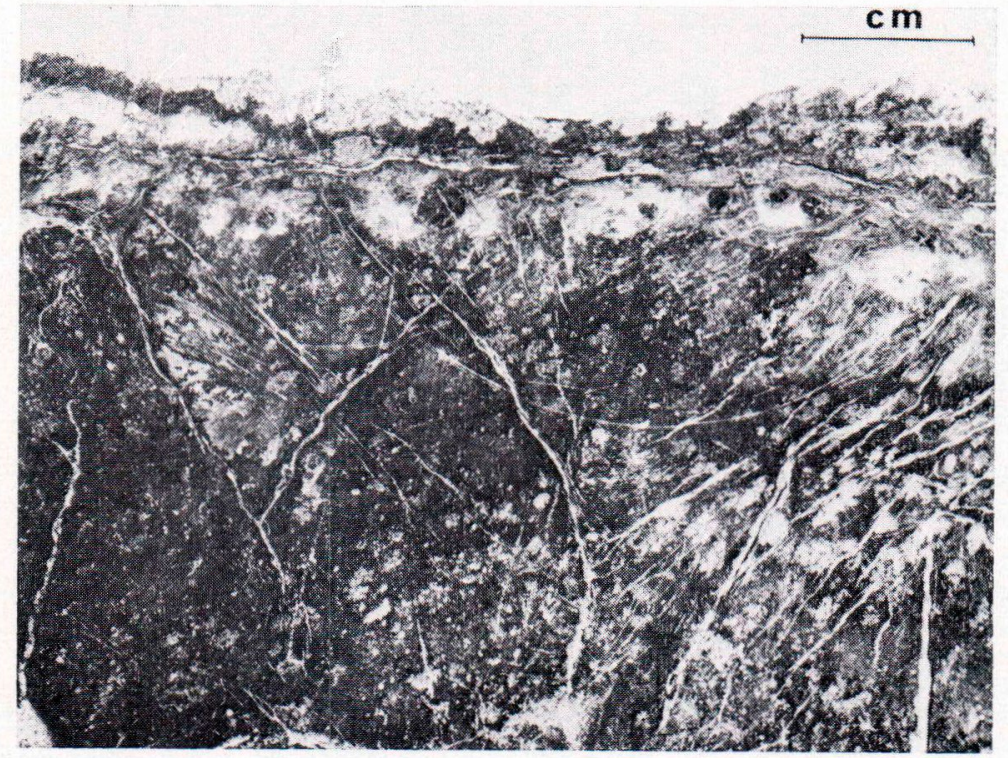

Fig. 7. Specimen 704-0113. Grunerite-garnet-biotite rock. Garnet crystals (white spots) and partly destroyed white chert bands in coarse poikiloblastic grunerite.

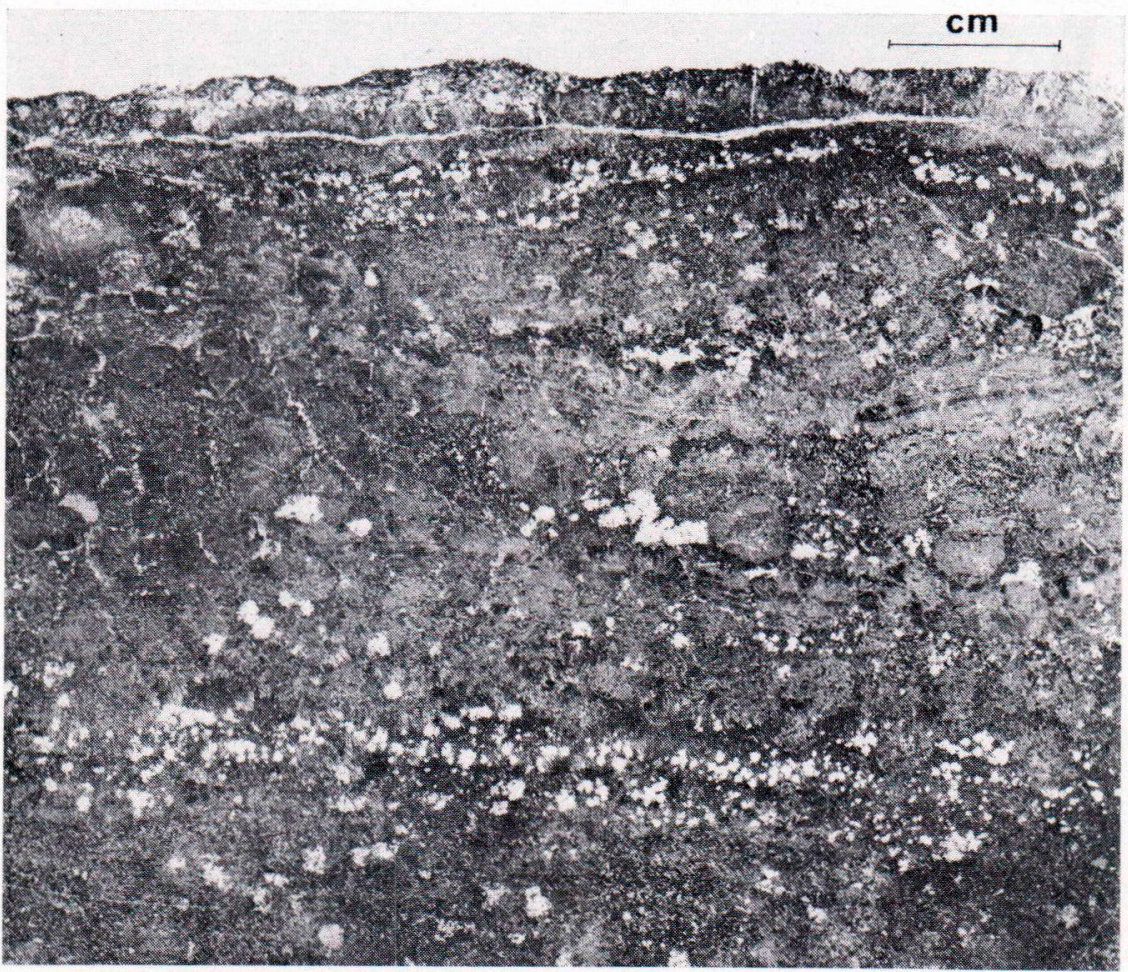

Fig. 8. Specimen 704-0107. Magnetite (white) dissemination in banded garnetgrunerite-biotite rock. 
quartz, magnetite, hematite, goethite, pyrrhotite and pyrite.

The rock is coarse grained: the lengths of grunerite crystals often exceed several centimetres. These poikiloblastic macrocrystals enclose garnet, biotite and goethite grains.

Specimen 704-0107 (Figs. 8 and 9)

The rock is composed of garnet, grunerite, biotite and magnetite with accessory quartz, carbonate, graphite and pyrrhotite.

The diameters of garnet grains are $4-6 \mathrm{~mm}$. The grains contain inclusions of amphibole, biotite, magnetite and a colorless alteration product. Zonal and lamellar structures appear as weak anisotrophism when viewed through crossed nicols.

The maximum lengths of the grunerite needles are appr. $2 \mathrm{~mm}$, average $0.3 \mathrm{~mm}$.

Biotite occurs as bands and individual grains $0.5 \mathrm{~mm}$ in diameter.

Magnetite is found mainly with grunerite crystals and in massive bands composed chiefly

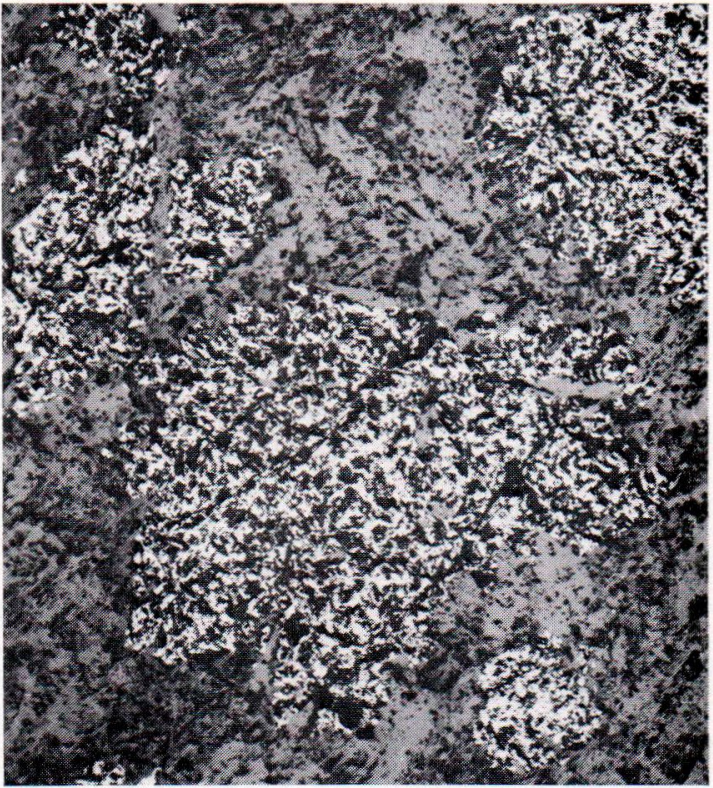

Fig. 9. Specimen 704-0107. Raggedy magnetite grains (white) in a silicate matrix. Polished section, nic.,$- \times 70$

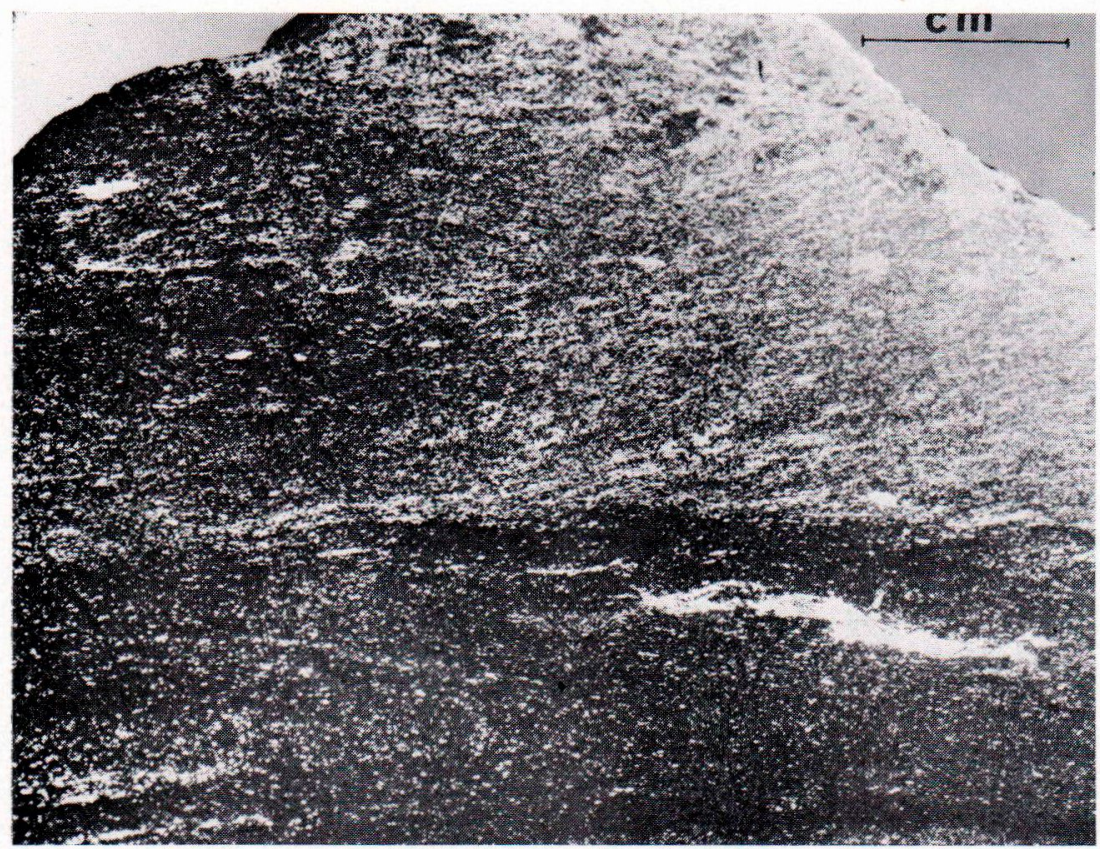

Fig. 10. Specimen 704-0126. Pyrrhotite (white) bands in quartz-biotitegraphite rock. 


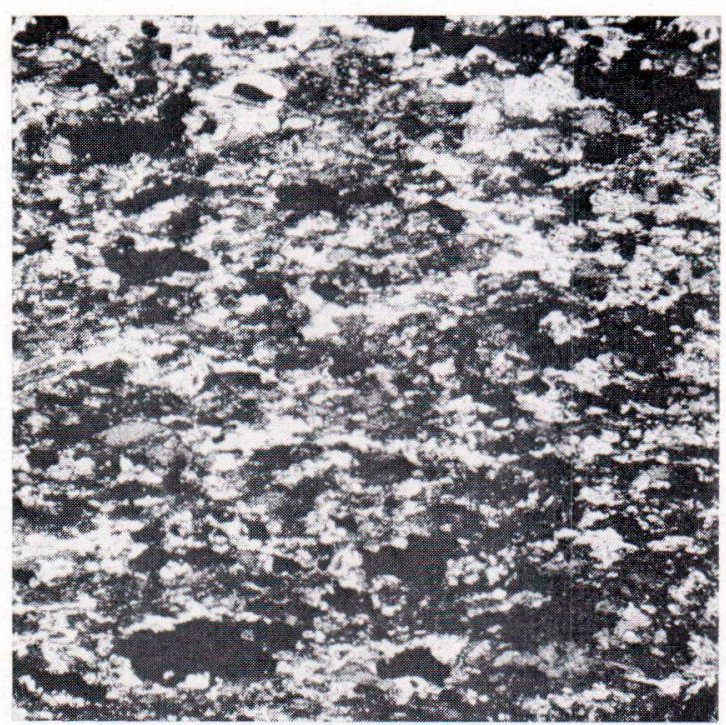

Fig. 11. Specimen 704-0126. Pyrrhotite (black), quartz (white), biotite (grey) and graphite (black »dust»). Thin section, nic.,$- \times 45$.

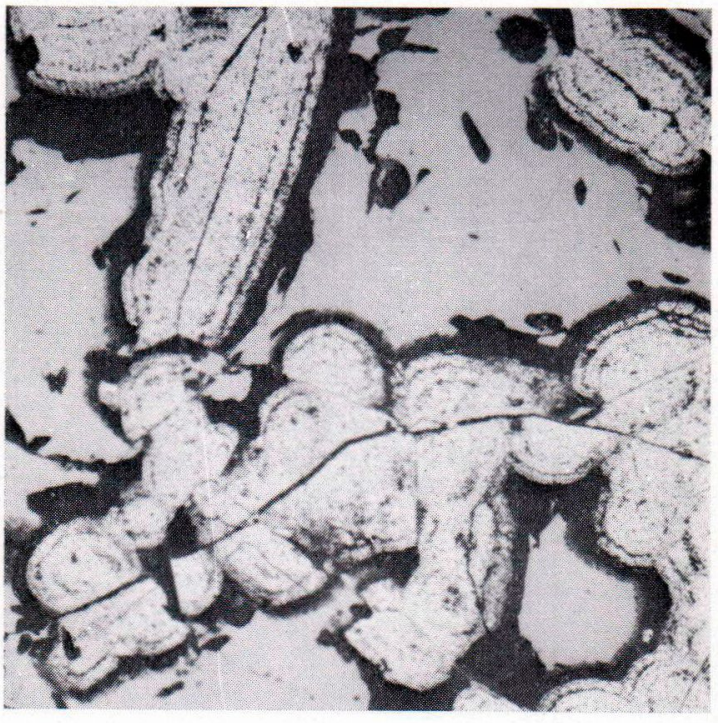

Fig. 12. Specimen 704-0126. Botryoidal marcasite (white) in pyrrhotite (grey). Polished section, nic.,$- \times 340$.

concentric textures. Similar marcasite was described by Ščeglova (1974) in the sulphides of the Komsomolskaya iron formation on the Kola peninsula, USSR.

The texture of the rock is granoblastic (sulphides, biotite), but at least some of the quartz grains might be regarded as blastoclastic.

A chlorite which appears to be of primary prograde origin has been found in specimen 704-0132 (Fig. 16). The mineral assemblage of this specimen is garnet-grunerite-chlorite (-quartz-carbonate-magnetite). There is no biotite in the thin section. The chlorite is fresh green, optically negative. The diameters of the well crystallized grains approximate $0.3 \mathrm{~mm}$. It occurs mainly in or at the edges of the raggedy garnet grains together with quartz, carbonate and amphibole needles. There are no indications of the chlorite being an alteration product, it looks more likely that it is a primary, prograde metamorphic mineral whose presence in the almandine-amphibolite facies can probably be contributed to the primary chemical com- 


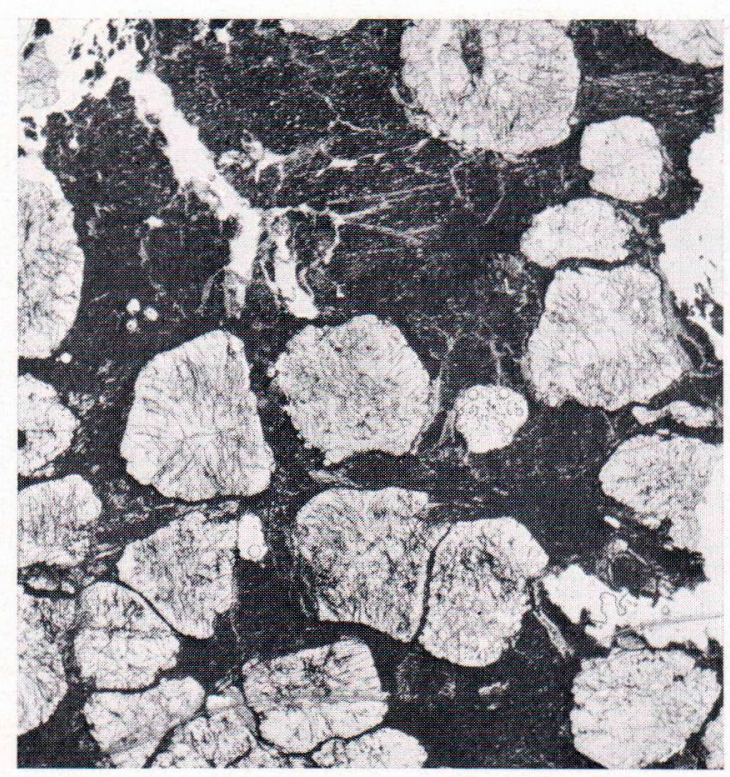

Fig. 13. Specimen 704-0125. Garnet (white) crystals in highly graphite pigmented grunerite-biotite matrix. Thin section, without microscope. $\times 3.5$.

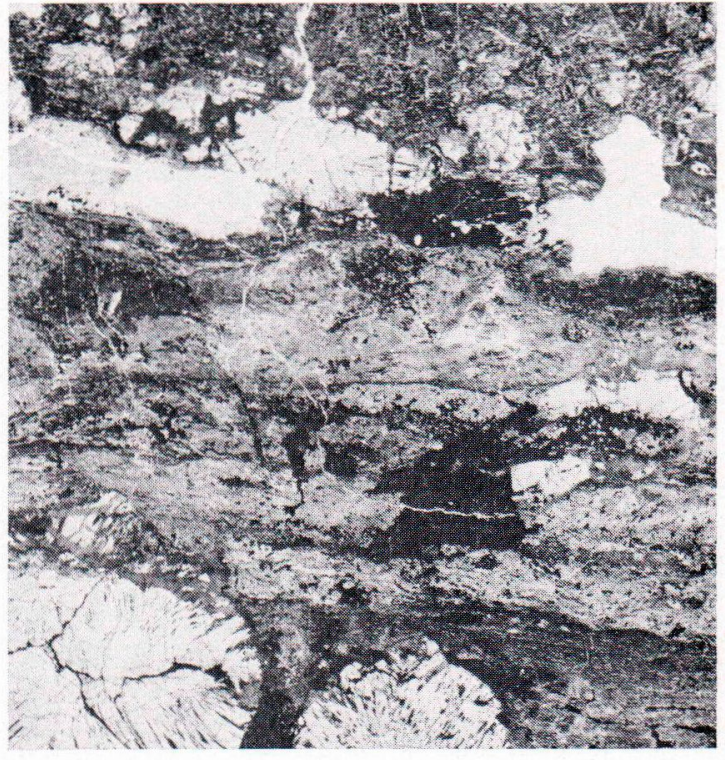

Fig. 15. Specimen 704-0237. Typically microbanded structure in garnet-grunerite-hornblende-quartz rock. No clastic grains visible. Thin section, without microscope, $\times 3.5$.

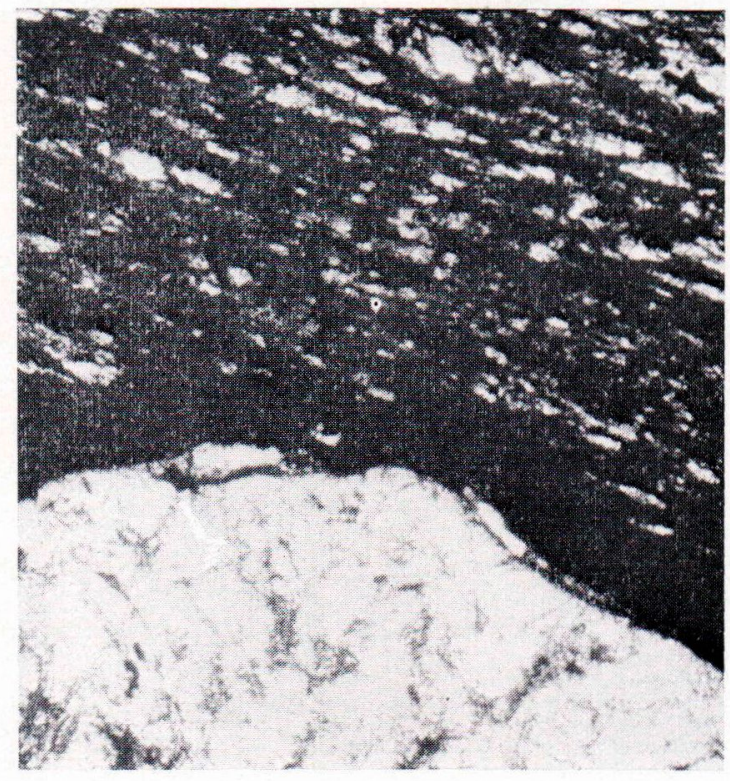

Fig. 14. Specimen 704-0125. Graphite (black) rims garnet (bottom, white), and occurs along the cleavage surfaces of a grunerite porphyroblast. Thin section, nic.,$- \times 45$.

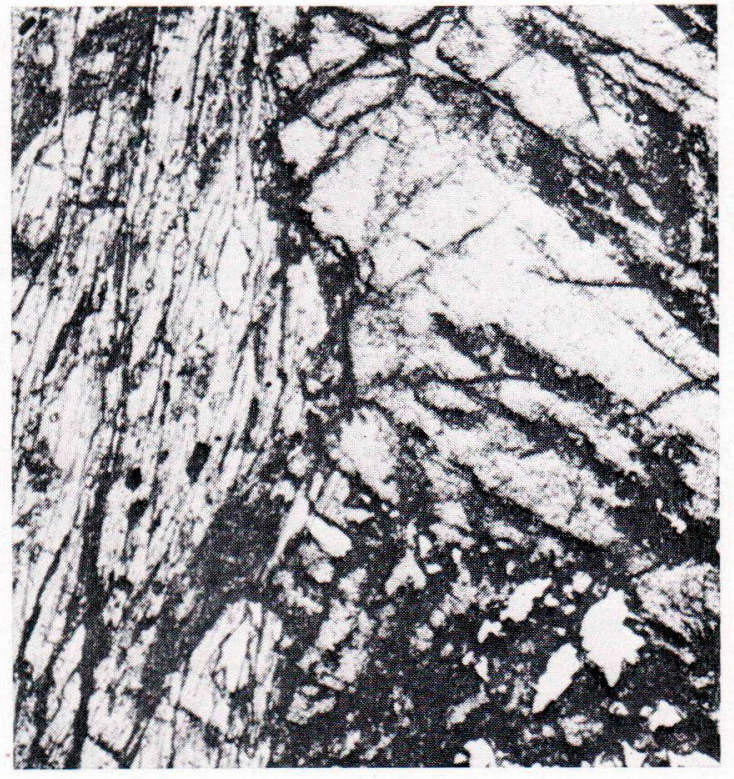

Fig. 16. Specimen 704-0132. Garnet (right, white) with chlorite (grey) intergrowths, and grunerite (left). Thin section, nic.,$- \times 45$. 


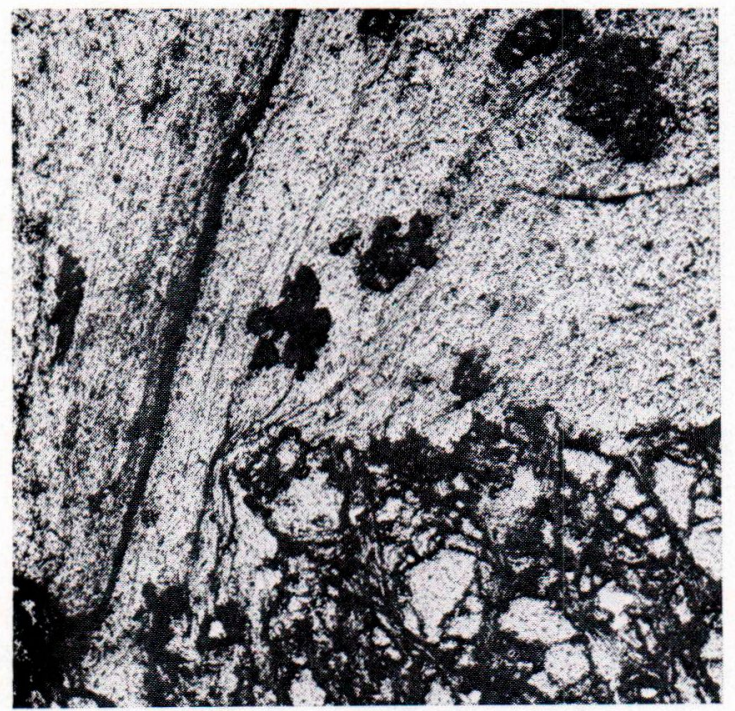

Fig. 17. Specimen 579-0089. Highly chloritized garnet (white, bottom) and chlorite (retrograde after biotite) with sphene crystals. Thin section, nic.,$- \times 45$.

position of the whole rock (deficiency in $\mathrm{K}_{2} \mathrm{O}$ ).

A clearly retrograde chlorite occurs in specimen 579-0089 from Tuomivaara. The original garnet-biotite rock has been altered into the paragenesis garnet-chlorite-sphene (Fig. 17). Some of this yellowish green chlorite still shows a brownish pleochroic tint and relatively high interference colors, which refer to the parent mineral, biotite.

Phyllite (Kalevian). Stratigraphically above the iron formation there are phyllites with local conglomerates. Quartzites also belong to this suite. In addition, graphiteand sulphide-bearing black schists and, further to the west towards the internides (Aubouin 1965) of the geosyncline, basic volcanics, related sediments, gabbroic rocks and ultrabasics are encountered. These phyllites belong to the Kalevian stratigraphic unit (Väyrynen 1954; Simonen 1960, 1971). The distribution and the relations of the Jatulian and the Kalevian units are not quite clear in the Tuomivaara area, but this is a problem of its own and is out of the scope of this account.

Unlike the Jatulian phyllites, the Kalevian phyllites locally contain conglomerates. The pebble material of these conglomerates mostly consists of quartz, quartzite, and phyllite. These conglomerates have not been found to contain pebbles of the iron formation (although a more careful investigation might reveal some), but they contain pebbles of the garnet-bearing phyllite that lies immediately below the iron formation.

The Kalevian phyllites with associated volcanics are thought to represent flysch sedimentation whose commencment marks the culmination between the evolutionary (Jatulian) and the revolutionary (Kalevian) phases of the Svecokarelian orogeny.

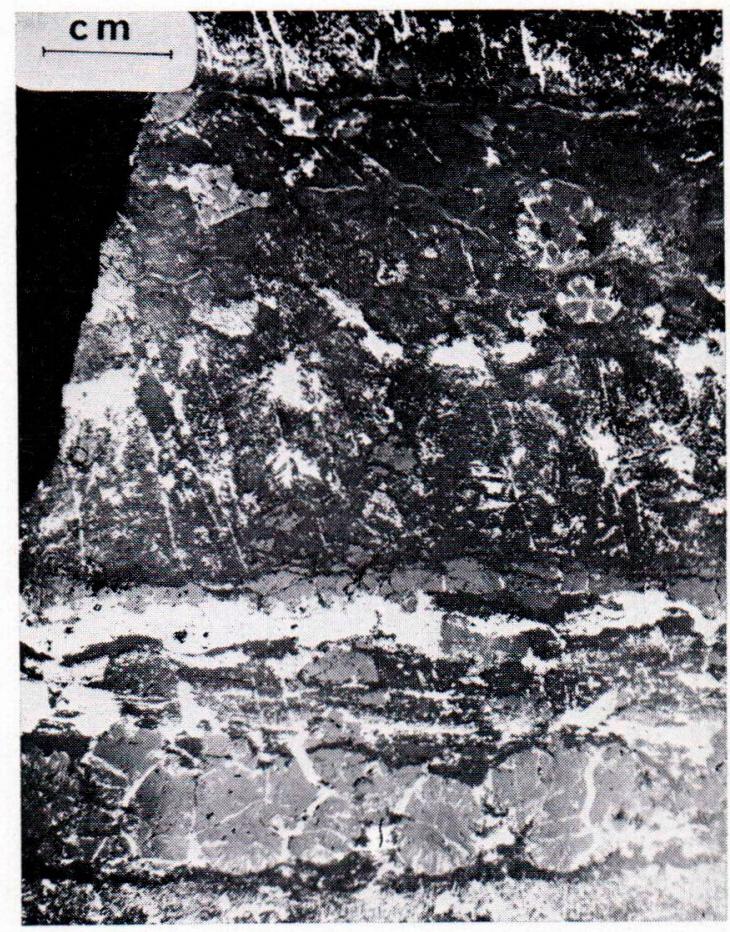

Fig. 18. Specimen 704-0237. Pyrrhotite (white) bands alternating with iron silicate (garnet, grunerite, biotite) bands. The pyrrhotite is partly mobilized filling cracks in silicate layers and crystals. 


\section{Structure}

The Tuomivaara area is characterized by North-South striking strata, generally dipping steeply $\left(70^{\circ}-80^{\circ}\right)$ to the West. This is also the general direction of the axial plane schistosity. The direction of the regional fold axis is appr. N-S its plunge being close to horizontal.

The strata are usually isoclinically steeply folded. This can be seen especially on the phyllite and iron formation outcrops. This results in the repetition of beds hindering the estimation of true thicknesses.

A peculiar feature is the rather large scale drag folding (or possibly cross folding) of the strata at Tuomivaara, which produces a fold pattern resembling the letter $\mathrm{Z}$ on the geological map (Figs. 1 and 2). According to the drilling data, this "Tuomivaara syncline» is sharp bottomed, plunging appr. $40^{\circ} \mathrm{NW}$, with a V-shaped cross section. From the economic standpoint this structure, together with the isoclinal folding, would be a favourable feature diminishing the stripping ratio in open pit construction, should only the grade and concentratability of the ore be better.

\section{Metamorphism}

The Tuomivaara area has been regionally metamorphosed by the Svecokarelian orogeny. The following silicate mineral parageneses (with quartz and carbonate) are typical of the rocks of the Tuomivaara iron formation:

- garnet - biotite - quartz

- garnet - grunerite - biotite - quartz (-carbonate)

- garnet - grunerite - hornblende - quartz

- garnet - grunerite - chlorite - quartz carbonate.

Iron oxides and sulphides also belong to these assemblages.

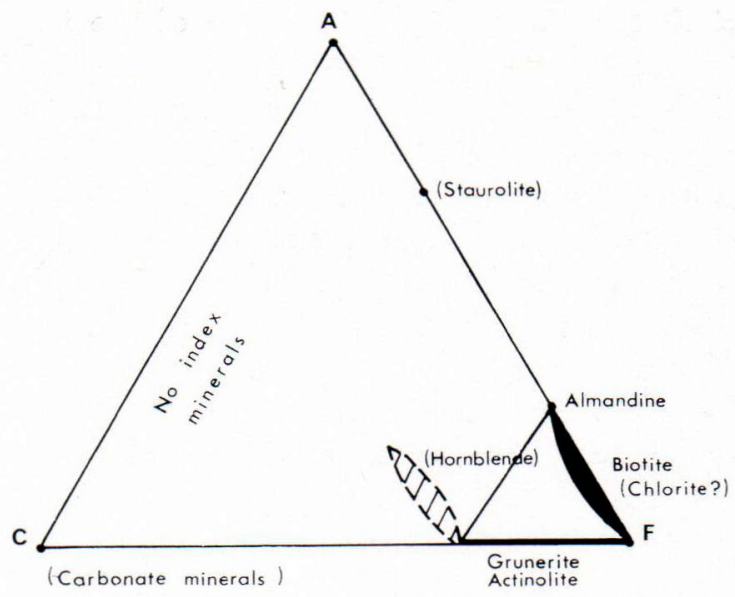

Fig. 19. ACF diagram for the Tuomivaara iron formation rocks. The constituent minerals are almandine, grunerite, biotite, and quartz. Hornblende and carbonate are less frequently encountered. Some of the chlorite may be of primary metamorphic origin. Staurolite occurs in the pelitic schists underlying the iron formation.

These mineral parageneses indicate the intermediate degree of metamorphism as detected by James (1955) in the iron formations of northern Michigan.

Fig. 19 is the ACF diagram for the Tuomivaara rocks. It must be noted that index minerals are lacking on the $\mathrm{AC}$ side because of the primary chemical composition. The existence of possibly prograde metamorphic chlorite in this facies, instead of biotite, is also likely to be due to the primary chemical composition. According to the classification of Turner and Verhoogen (1960), these assemblages would correspond to the almandine-amphibolite facies (staurolite-almandine subfacies). The mineral parageneses indicate the excess of $\mathrm{SiO}_{2}$ and the deficiency in $\mathrm{K}_{2} \mathrm{O}$.

\section{Economic aspects}

The total iron content is fairly constant, appr. $25 \mathrm{wt}-\%$, throughout the Tuomivaara 
iron formation. Appr. $5-15 \%$ of the iron is magnetite bound. The total amount of iron remains constant even when the corresponding amounts of iron bound to silicates, magnetite and sulphides vary. This is indicated by the drill core assay data. The only exception to this rule is the magnetite rich horizon close to the top of the iron formation. Here iron totals appr. $30 \%$, of which the magnetite iron accounts for appr. $20-25 \%$. Throughout the iron formation, the appr. $0.9 \%$ phosphorus, $1.5 \%$ sulphur and $1-2 \%$ graphite contents are also typical.

Economically the Tuomivaara iron formation is of low quality. The average amount of magnetite is small, and it is very fine grained usually occuring as ash-like dissemination in certain bands and in the porphyroblastically grown iron silicates. This makes the concentration of iron difficult: the magnetite is not liberated by normal milling, the concentrates contain mixed grains, and the recovery is poor. The high phosphorus and sulphur contents are also harmful factors in metallurgical processing.

\section{Discussion}

The origin of iron formations (or »banded iron formations») has been discussed by several authors (e.g. Nuutilainen and Mäkelä 1973). Regardless of the source and transport mechanism of iron the Eh- $\mathrm{pH}$ conditions in the sedimentary basin finally determine the facies of the precipitating iron formation.

An interesting approach to the explanation of the origin of iron formations from the geochemical standpoint has recently been taken by Drever (1974). It is explained that the upwelling iron bearing waters interfere with the atmosphere through evaporation and transport of oxygen, thus resulting in changes in the Eh-pH field and the precipitation of iron minerals. This geochemical model seems to fit to Finnish iron formations. This notion leads to the idea that the normally thinly banded (microbanding) structure of iron formations could represent periodic cycles (e.g. Trendall 1968). The thermal difference could speed up evaporation during warmer periods in the sedimentary basin and thus account for the precipitation. Days and nights and seasons are the only phenomena in nature that repeat themselves as regularly as do the microbands in iron formations. If the observed thicknesses of microbands (appr. $1 \mathrm{~mm}$ on an average in the Tuomivaara iron formation) represent daily cycles it would only take appr. 600 yrs. to precipitate the total $200 \mathrm{~m}$ thickness of the iron formation. This figure, however, seems unreasonably low. Hence it might be better to assume that the microbanding represents seasonal cycles, which, at a precipitation rate of $1 \mathrm{~mm} / \mathrm{yr}$., would require $200000 \mathrm{yrs}$. to build up the $200 \mathrm{~m}$ thick iron formation.

The banded structure of the Tuomivaara iron formation is also visible in geophysical data. The magnetic susceptibility measurements made in the drill holes at short intervals display certain regular undulations. This phenomenon could possibly be used to determine bottom directions (Professor Paarma, personal communication).

As to the origin of the iron silicates in the Tuomivaara iron formation, it is believed that the presently existing grunerite, garnet and biotite are metamorphic equivalents of the pre-existing, originally primary, silicates. There are no definite indications of reactions between carbonate and quartz; only it seems likely that the silicate facies, being most sensitive to the changes of mineral phases in prograde metamorphism, represents a transformational series from diagenetic silicate(s) to low grade metamorphic, and 
further to intermediate grade metamorphic minerals: grunerite, almandine and biotite.

The presently known length of the Tuomivaara iron formation belt is appr. $20 \mathrm{~km}$, and it is expected to continue consistently. It is easily recognized in the field and on the (aero)geophysical maps. It thus makes an excellent marker horizon in the Karelian schist zone. Iron formations have recently been found in the geological reconnaissance by Rautaruukki Oy. also elsewhere in the Karelian schist zone, and an iron ore deposit, probably on the stratigraphic continuation of the Tuomivaara belt, is being investigated by the Geological Survey of Finland at Puolanka (Geological Survey of Finland, Annual Report 1973, pp. 23-26). There the oxide facies is also present; there is probably a lateral change from a silicate facies to an oxide facies.

There are a few reports published on iron formations and related rocks in Finland during the recent years (e.g. Paakkola 1971; Laajoki 1973; Nuutilainen and Mäkelä 1973; Geo- logical Survey of Finland, Annual Report 1973; Lavikainen 1973). The recognization of the concept of iron formation is important, not only from the point of view of the national raw material supply, but also from the standpoint of base metal exploration: the strata bound massive iron sulphide deposits, with or without economic value in base and precious metals, can simply be explained as the sulphide facies of an iron formation (e.g. Stanton, 1972). Together with other geological and geophysical data, the iron formations, with their facies controlled by the sedimentary environment, give valuable information for both geological basic research (e.g. basin analysis) and mineral exploration.

Acknowledgements - The author wishes to express his gratitude to the following Rautaruukki Oy. personnel: Professor Heikki Paarma and Dr. Juhani Nuutilainen for reading the manuscript with constructive criticism, Mr. Jouko Penninkilampi for taking the photographs of the rock specimens and thin sections without microscope, and Mrs. Anja Palosaari for drafting the figures 1, 2,3 and 19 .

\section{REFERENCES}

Aubouin, J. (1965) Geosynclines. Elsevier, Amsterdam.

Drever, J. I. (1974) Geochemical Model for the Origin of Precambrian Banded Iron Formations. Geol. Soc. Am. Bull. 85: 1099-1106.

James, H. L. (1955) Zones of Regional Metamorphism in the Precambrian of Northern Michigan, Bull. Geol. Soc. Am. 66: 1455-1488 Laajoki, K. (1973) On the geology of the South Puolanka area, Finland. Geol. Surv. Finland Bull. 263. 54 p.

Lavikainen, S. (1973) [Map of Pre-quaternary rocks], 4244 Ilomantsi. Geological Map of Finland, $1: 100000$.

Nuutilainen, J. and Mäkelä, K. (1973) On Banded Iron Formations in Northern Finland. XI Nordiska geologiska vintermötet. Oulu/Uleåborg. 1974, Januari 3-5, A. Föredragstexter utgivna före mötet, pp. $37-43$.
Paakkola, J. (1971) The volcanic complex and associated manganiferous iron formation of the Porkonen-Pahtavaara area in Finnish Lapland. Bull. Comm. Géol. Finlande 247. 83 p.

Simonen, A. (1960) Pre-Quaternary rocks in Finland. Bull. Comm. Géol. Finlande 191. 49 p.

- (1971) Das finnische Grundgebirge. Geol. Rundsch. 60 (4): 1406-1421.

Ščeglova, T. P. (1974)

Щеглова, Т. П. (1974) Метасоматизм при формировании железистых кварцитов Комсомольского месторождения. Геология рудньг месторождений, том XVI, 5, Академия Наук CCCP

Stanton, R. L. (1972) Ore Petrology. McGraw-Hill, New York. 713 p.

Suominen, P. (1956) Tuomivaaran alueen geologiaa. Master's thesis. Manuscript. Dept. of Geol., Univ. of Helsinki. 
Trendall, A. F. (1968) Three Great Basins of Precambrian Banded Iron Formation Deposition: A Systematic Comparison. Geol. Soc. Am. Bull. 79: 1527-1544.

Turner, F. and Verhoogen, J. (1969) Igneous and metamorphic petrology. Sec. ed. McGraw-Hill, New York.

Väyrynen, H. (1933) Über die Stratigraphie der Karelischen Formationen. C.R. Soc. Géol. Finlande 6. Bull. Comm. Géol. Finlande 101: 54-78.
- (1954) Suomen Kallioperä. Otava, Helsinki Wilkman, W. W. (1921) Vuorilajikartan selitys, lehti D 4, Nurmes. Suomen Geologinen Yleiskartta. $1: 400000$.

- (1924) [Map of Pre-Quaternary rocks], sheet D 4 Nurmes. General Geological Map of Finland, $1: 400000$.

Manuscript received, November 29, 1975. 